\title{
Fumigant dosages below maximum label rate control some soilborne pathogens
}

by Shachaf Triky-Dotan, Becky Westerdahl, Frank N. Martin, Krishna Subbarao, Steven T. Koike and Husein A. Ajwa

The activity of commercial soil fumigants on some key soilborne pathogens was assessed in sandy loam soil under controlled conditions. Seven soil fumigants that are registered in California or are being or have been considered for registration were used in this study: dimethyl disulfide (DMDS) mixed with chloropicrin (Pic) (79\% DMDS and $21 \%$ Pic), Tri-Con (50\% methyl bromide and 50\% Pic), Midas Gold (33\% methyl iodide [MI] and $67 \%$ Pic), Midas Bronze (50\% MI and 50\% Pic), Midas (MI, active ingredient [a.i.] 97.8\%), Pic (a.i. 99\% trichloronitromethane) and Pic-Clor 60 (57\% Pic and 37\% 1,3-dichloropropene [1-3,D]). Dose-response models were calculated for pathogen mortality after 24 hours of exposure to fumigants. Overall, the tested fumigants achieved good efficacy with dosages below the maximum label rate against the tested pathogens. In this study, Pythium ultimum and citrus nematode were sensitive to all the fumigants and Verticillium dahliae was resistant. For most fumigants, California regulations restrict application rates to less than the maximum (federal) label rate, meaning that it is possible that the fumigants may not control major plant pathogens. This research provides information on the effectiveness of these alternatives at these lower application rates. The results from this study will help growers optimize application rates for registered fumigants (such as Pic and 1,3-D) and will help accelerate the adoption of new fumigants (such as DMDS) if they are registered in California.

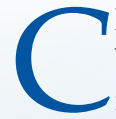
hemical fumigants control soilborne pathogens and weeds in many crop production systems. Methyl bromide (MBr) was the most commonly used preplant soil fumigant during the last 40 years. The California strawberry industry - valued at approximately $\$ 2.6$ billion in 2014 (California Strawberry Commission 2016) - was highly dependent on $\mathrm{MBr}$ soil fumigation to control various soil pests and to maintain high productivity, as there are no disease-resistant strawberry varieties. $\mathrm{MBr}$ effectively controls a wide range of soilborne pathogens, diffuses through soil effectively and dissipates from soil rapidly. However, MBr has been phased out under the Montreal Protocol because it is an ozone-depleting compound.

As a result of this phaseout, which began in 2001, the use of alternative fumigants such as 1,3-dichloropropene (1,3-D) and chloropicrin (trichloronitromethane) has increased (CDPR 2009). In addition, 1,3-D and chloropicrin are being used in combination to improve soil disinfestation effectiveness (Ajwa et al. 2003; Gamliel and Triky-Dotan 2009; Martin 2003). Klose et al. (2007) developed logistic dose-response models for InLine (61\% 1,3-D and 33\% chloropicrin) efficacy against soilborne pathogens and weed seeds in sandy loam soil. Now, with the recent introduction of new commercial

Online: http://dx.doi.org/10.3733/ca.2016a0004

A dose-response study of soil fumigants found that some soilborne pathogens can be controlled at application rates that are lower than the maximum label rate. 
formulations of fumigants (e.g., Pic-Clor 60 , a mixture of $57 \%$ chloropicrin and $37 \%$ $1,3-\mathrm{D})$, there is a need to conduct similar dose-response evaluations of pathogen sensitivity to them.

In the past decade, research on alternative fumigants has focused on finding effective application rates for the various application methods, such as drip fumigation and fumigant applications under low permeability films. More recently, due to federal and state regulations (CDPR 2009; USEPA 2015), research has increasingly focused on methods to reduce fumigant atmospheric emissions. These new federal and state regulations limit application rates of fumigants in order to reduce exposure risk to farmworkers and bystanders and to limit air pollution from release of volatile organic compounds (VOC) that form ground-level ozone (smog).

The new fumigant application rates are considerably lower than the previously allowed rates and may not adequately control soilborne pathogens and weeds. Currently, soil fumigants are usually applied under standard polyethylene tarp, which is highly permeable and allows large amounts of fumigants to escape into the atmosphere (Gao et al. 2013). Recent research has evaluated the potential for impermeable films to reduce fumigant emissions and to enhance the efficacy of low application rates. Tarping fields with low permeability film, such as virtually impermeable film (VIF) or totally impermeable film (TIF), has been effective in retaining fumigants in soil (Gao et al. 2013). These films can improve the efficacy of reduced fumigant application rates because they retain higher fumigant concentration and extend the exposure time (concentration $\times$ time) under the film compared to standard polyethylene film (Fennimore and Ajwa 2011; Qin et al. 2011).

A new $\mathrm{MBr}$ alternative, dimethyl disulfide (DMDS), recently received a federal registration and is being considered for registration in California. Previous studies assessed the technical formulations (98\% to $99 \%$ ) of DMDS and showed that it is biologically effective against citrus nematode (Tylenchulus semipenetrans; Cabrera et al. 2010) and several soilborne pathogens: Sclerotinia sclerotiorum, Sclerotium rolfsii, Rhizoctonia solani and Phytophthora cactorum (Fritsch et al. 2002). Limited dose-response data are available on DMDS, however, and no information

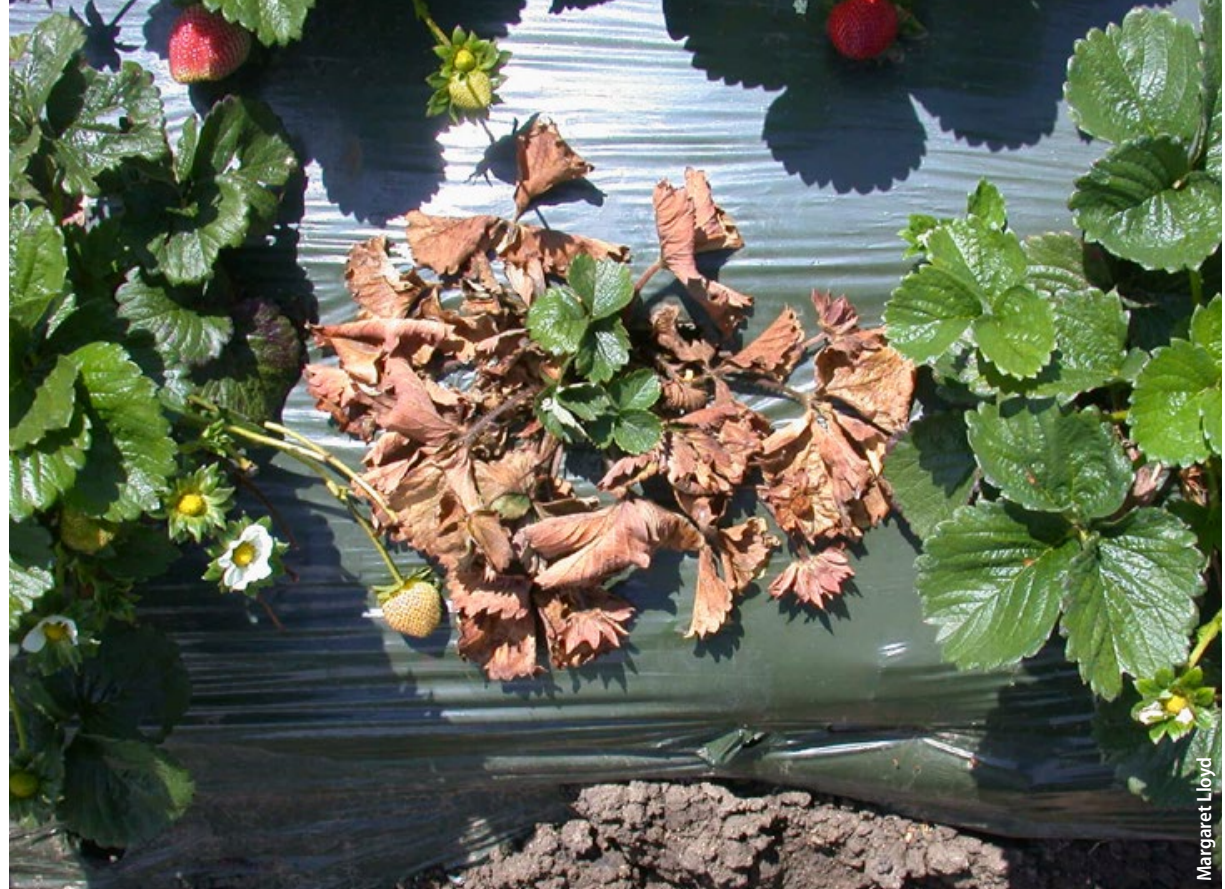

A strawberry plant affected by Vertcillium wilt.

is available on the proposed commercial formulation with chloropicrin (Pic), DMDS:Pic (79:21).

One additional $\mathrm{MBr}$ alternative assessed in the current study is methyl iodide (MI), which received a federal registration in 2007 and a California registration in December 2010. Laboratory dose-response studies - which determine the relationship between the amount of fumigant and its effect on an organism - have indicated that MI is as effective as or more effective than $\mathrm{MBr}$ to control soilborne pathogens and weeds (Becker et al. 1998; Hutchinson et al. 1999; Hutchinson et al. 2000; Luo et al. 2010; Ohr et al. 1996). MI has a synergistic relationship with chloropicrin under controlled conditions, similar to the relationship between $\mathrm{MBr}$ and chloropicrin (Hutchinson et al. 2000). However, in March 2012, all MI registrations were withdrawn by the manufacturer. Nevertheless, it may be reintroduced in the future, and the MI data presented here is helpful for understanding the role of fumigant chemistry in the mobility and efficacy of fumigants.

When registering a new fumigant, dose-response studies are not required and efficacy studies usually are conducted for only the pure product. Commercial fumigant formulations may contain several active ingredients; however, the efficacy rate is typically determined for a single active ingredient for a specific target pathogen (i.e., control of certain fungal pathogens, nematodes and weeds) and specific crops. However, the synergistic relationship caused by mixing two fumigants can enhance efficacy compared with fumigants applied alone (Hutchinson et al. 2000).

Our earlier research developed doseresponse data for InLine (61\% 1,3-D and $33 \%$ chloropicrin) (Klose et al. 2007). The use of 1,3-D has been capped at 90,250 pounds per year per township (36-squaremile area). With this restriction on the amount of 1,3-D that can be used in California, a new commercial formulation, Pic-Clor 60, was recently introduced into the market and is being used as a replacement for InLine. The dose-response data developed for InLine, however, may not be valid for Pic-Clor 60 .

The objective of this study was to develop a dose-response model for tested soil fumigants controlling soilborne pathogens in a sandy loam soil; this soil type was selected because it represents over $80 \%$ of soils that are used for strawberry production in California. Doseresponse models help determine the optimum fumigant and fumigation rate to control soilborne pathogens.

\section{Soil and chemicals}

Soil samples were collected from the upper soil layer (5 to 20 centimeters depth) from a commercial field in Salinas, California (Chualar loam series, fine-loamy, mixed, thermic, Typic Argixerolls), that had not been fumigated in the last 5 years. Soil characteristics were $10 \%$ of clay, $15 \%$ of silt and $75 \%$ of sand; organic matter, $0.9 \mathrm{~g} \mathrm{~kg}^{-1}$; moisture content, $10 \%$; and $\mathrm{pH}$, 
7.0 (determined in 1:1 water extract [wt/ $\mathrm{wt}]$ ).

The fumigants used in this study were chloropicrin (Pic 99, active ingredient [a.i.] 99\%, Niklor-Tri-Cal Inc., Mojave, California), Pic-Clor 60 (57\% Pic:37\% 1,3-D, Tri-Cal Inc., Hollister, California), DMDS:Pic (79\% DMDS:21\% Pic, United Phosphorus Inc., King of Prussia, Pennsylvania), Tri-Con (50\% MBr:50\% Pic, Tri-Cal Inc., Hollister, California), Midas (MI, a.i. 97.8\%, Arysta LifeScience, Cary, North Carolina), Midas Bronze (50\% MI:50\% Pic, Arysta LifeScience, Cary, North Carolina) and Midas Gold (33\% MI:67\% Pic, Arysta LifeScience, Cary, North Carolina).

Except for methyl isothiocyanate generators (e.g., metam sodium), these fumigants represent most of the soil fumigants registered by the U.S. Environmental Protection Agency. Studies on the efficacy of methyl isothiocyanate generators to control soilborne pathogens were presented by Klose et al. (2008).

\section{Experimental setup}

Inoculum bags of soilborne pathogens Fusarium oxysporum, Pythium ultimum, R. solani, Verticillium dahliae and T. semipenetrans were prepared as described by Klose et al. (2007, 2008). These pathogens were selected because they affect a wide variety of high-valued crops in California, such as strawberry $(V$. dahliae can cause a complete strawberry crop failure or severe economic loss), cut flower, vegetables and several perennial crops (Ajwa et al. 2003; Klose et al. 2007).

Inoculum bags were buried in 500gram samples of field-collected nonsterile sandy loam soil placed in 1-liter glass laboratory containers. Tap water (55 milliliters) was added drop-wise via pipette to cover the whole soil surface 48 hours before fumigation to activate the tested pathogens. The various fumigant solutions and an additional 20 milliliters of water were incorporated into the soil to bring final soil water content to $80 \%$ of field capacity.

Six fractional concentrations $(100 \%$, $75 \%, 50 \%, 37.5 \%, 25 \%$ and $12.5 \%$ ) of the maximum label rate of each fumigant were assessed. For example, Tri-Con (50\% $\mathrm{MBr}: 50 \%$ Pic) was applied to the soil to achieve final concentrations in the soil of $100 \%, 75 \%, 50 \%, 37.5 \%, 25 \%$ and $12.5 \%$ of the label rate, which is equal to $2,448.8$, 1,836.6, 1,224.4, 9,06.0, 612.2 and $306.1 \mu \mathrm{mol}$ $\mathrm{kg}^{-1}$ (dry $\mathrm{wt}$ ). The maximum rate is equivalent to a field application of 336 kilograms per hectare $\left(\mathrm{kg} \mathrm{ha}^{-1}\right)$ or 300 pounds per acre $\left(\mathrm{lb} \mathrm{ac}^{-1}\right)$. The maximum soil concentration for each fumigant was 5,494.9 $\mu \mathrm{mol} \mathrm{kg}{ }^{-1}$ for DMDS:Pic (79:21), 2,448.8 $\mu \mathrm{mol} \mathrm{kg}{ }^{-1}$ for MBr:Pic (50:50), 1,886.6 $\mu \mathrm{mol}$ $\mathrm{kg}^{-1}$ for MI:Pic (33:67), 1,612.3 $\mu \mathrm{mol} \mathrm{kg}{ }^{-1}$ for MI:Pic (50:50), $836.4 \mu \mathrm{mol} \mathrm{kg} \mathrm{kg}^{-1}$ for MI:Pic (98:2), 1,775.1 $\mathrm{mmol} \mathrm{kg}^{-1}$ for Pic 99 and 2,004.7 $\mu \mathrm{mol} \mathrm{kg}^{-1}$ for Pic-Clor 60 (57:37).

Soil samples without fumigants were treated with tap water only and served as a control. The experimental setup included a total of 172 glass containers ( 7 fumigants $\times 6$ concentrations $\times 4$ replicates plus 4 control replicates). The treated containers were sealed with caps to prevent fumigant escape and were incubated for 24 hours at $20^{\circ} \mathrm{C}$, then aerated for an additional 24 hours.

Pathogen mortality was assessed by counting the number of viable nematodes or fungal colony forming units relative to untreated controls as previously described by Klose et al. (2007, 2008). The field application rate $\left(\mathrm{kg} \mathrm{ha}^{-1}\right)$ was converted to $\mathrm{mg} \mathrm{kg}^{-1}$ by assuming soil bulk density of $1.3 \mathrm{~g} \mathrm{~cm}^{-3}$ and a depth of
30 centimeters. The experiment was conducted in June 2010, and repeated in July 2010.

\section{Statistical analysis}

The experiment was arranged as a complete randomized block with four replicates. Dose-response relationships between fumigant concentration and mortality of pathogens were computed using a sigmoidal fit model using $R^{2}$ values and standard error estimates.

$$
\text { Equation: } \quad Y=\frac{a}{1+e-\left(\frac{x-x 0}{b}\right)}
$$

where $Y$ is the pathogen mortality (percent mortality relative to an untreated control) as a function of the fumigant concentration $(x)$ and $b$ is the slope of the curve at the inflection point. The value $b$ represents the maximum value of the slope and indicates the dose where the probability of pathogen mortality becomes greater than $50 \%$.

Sigmoidal probability models were computed using SigmaPlot 2001 version 10 (Systat Software Inc., Point Richmond, California). Dose-response curves were used to estimate the fumigant concentration required to achieve pathogen mortality of $50 \%\left(\mathrm{LC}_{50}\right)$ using the SAS probit procedure (SAS Institute Inc., Cary, North Carolina, release 9.1 for $P C$ ) at $P \leq 0.05$.

The minimum inhibitory concentration $\left(\mathrm{MIC}_{80}\right)$ - the application rate that results in $80 \%$ mortality — is the standard method for determining the susceptibility of organisms to antimicrobial agents. It is calculated for each fumigant and pathogen by using two actual dosage values that bracket the $80 \%$ pathogen mortality rate (one value below the $80 \%$ mortality rate, one above) and then calculating the dosage that falls on the line joining these two dosage values that would achieve an $80 \%$ mortality rate.

\section{Results}

\begin{tabular}{lccccc}
\hline \hline & \multicolumn{5}{c}{ Soilborne pathogen } \\
\cline { 2 - 6 } Main effect & $\begin{array}{c}\text { Fusarium } \\
\text { oxysporum }\end{array}$ & $\begin{array}{c}\text { Pythium } \\
\text { ultimum }\end{array}$ & $\begin{array}{c}\text { Rhizoctonia } \\
\text { solani }\end{array}$ & $\begin{array}{c}\text { Tylenchulus } \\
\text { semipenetrans }\end{array}$ & $\begin{array}{c}\text { Verticillium } \\
\text { dahliae }\end{array}$ \\
\hline Fumigant & $P<0.0001$ & $P<0.0001$ & $P<0.0001$ & NS* & NS \\
Concentration & $P<0.0001$ & $P<0.0001$ & $P<0.0001$ & $P<0.0001$ & $P<0.0001$ \\
Fumigant $\times$ concentration & $P<0.0001$ & $P<0.0001$ & $P<0.0001$ & NS & NS \\
\hline
\end{tabular}

Soil fumigants: DMDS plus Pic (79\% DMDS:21\% Pic), Tri-Con (50\% MBr:50\% Pic), Midas Gold (33\% Ml:67\% Pic), Midas Bronze (50\% Ml:50\% Pic), Midas (MI, a.i. 97.8\%), Pic (trichloronitromethane) (a.i. 99\%) and Pic-Clor 60 (57\% Pic:37\% 1,3-D). Each fumigant was applied to the soil to achieve final concentrations in the soil of $100 \%, 75 \%, 50 \%, 37.5 \%, 25 \%$ and $12.5 \%$ of the label rate.

${ }^{*} \mathrm{NS}=$ Not significant at $P>0.05$.

\section{A multivariate analysis of variance} (ANOVA) was run to determine the effects of soil fumigants, application rates and the interactions between these two factors on the mortality of soilborne pathogens (table 1). This table indicates that regardless of the fumigant, application rate significantly affects mortality of all pathogens tested. In addition, table 1 
indicates that the type of fumigant and fumigant/concentration combination significantly affects mortality of F. oxysporum, P. ultimum and R. solani. However, for $T$. semipenetrans and $V$. dahliae, the type of fumigant and fumigant/concentration combination did not significantly impact

\section{The mortality results ... reveal that P. ultimum}

\section{and $\mathrm{T}$. semipenetrans were sensitive to the fumigants and V. dahliae was more resistant.}

mortality. To further investigate these results, dose-response curves were fit to each pathogen and fumigant combination for each concentration. An example of the dose-response curves representing the mortality rates for MBr:Pic and each pathogen is in figure 1.

As part of the dose-response analysis, slope and lethal concentration ( $\left.\mathrm{LC}_{50}\right)$ values were calculated from the doseresponse curves (tables 2 and 3). In table 2 , the calculated values of the slope $(b)$, which indicates the susceptibility of the pathogens to the fumigant, were not significant $(P>0.18-0.99)$ for $P$. ultimum and T. semipenetrans because $100 \%$ mortality was achieved at the lowest dosages. By contrast, $V$. dahliae did not achieve a $100 \%$ mortality rate at any dosage, so the calculated slope was not significant. The mortality results in tables 2 and 3 reveal that $P$. ultimum and T. semipenetrans were sensitive to the fumigants and $V$. dahliae was more resistant.

\section{DMDS:Pic}

The DMDS:Pic fumigant controlled $P$. ultimum and T. semipenetrans even at low dosages (tables 2 and 3). The lethal concentration required to control $50 \%\left(\mathrm{LC}_{50}\right)$ of $P$. ultimum and T. semipenetrans were 507.0 and $588.5 \mu \mathrm{mol} \mathrm{kg}{ }^{-1}$, respectively (table 3). Also, low values of the $\mathrm{MIC}_{80}$ for P. ultimum and T. semipenetrans were $1,460.3$ and 730.6 $\mu \mathrm{mol} \mathrm{kg}{ }^{-1}$, respectively (table 4). The $\mathrm{LC}_{50}$ values for F. oxysporum and $R$. solani following DMDS:Pic application were about one-fifth of the full concentration (table 3$)$. The full concentration of DMDS:Pic resulted in only $60 \%$ mortality of $V$. dahliae (data not shown). The $\mathrm{MIC}_{80}$ value for $V$. dahliae was 3,750.8 $\mu \mathrm{mol} \mathrm{kg}{ }^{-1}$ as calculated by the linear

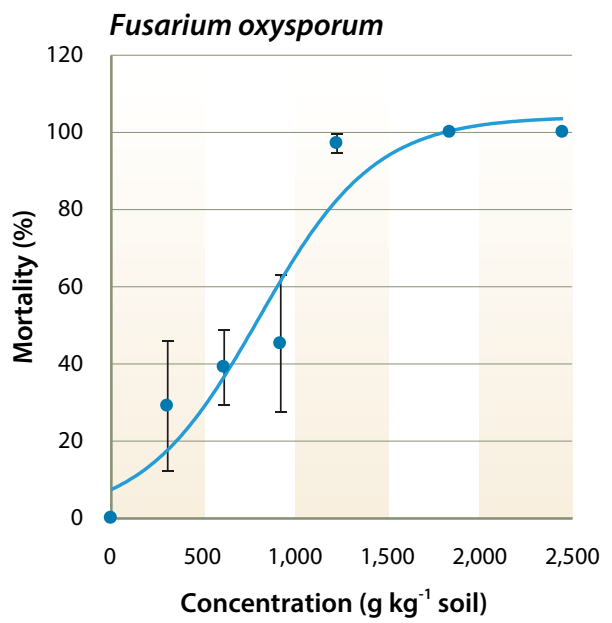

Tylenchulus semipenetrans
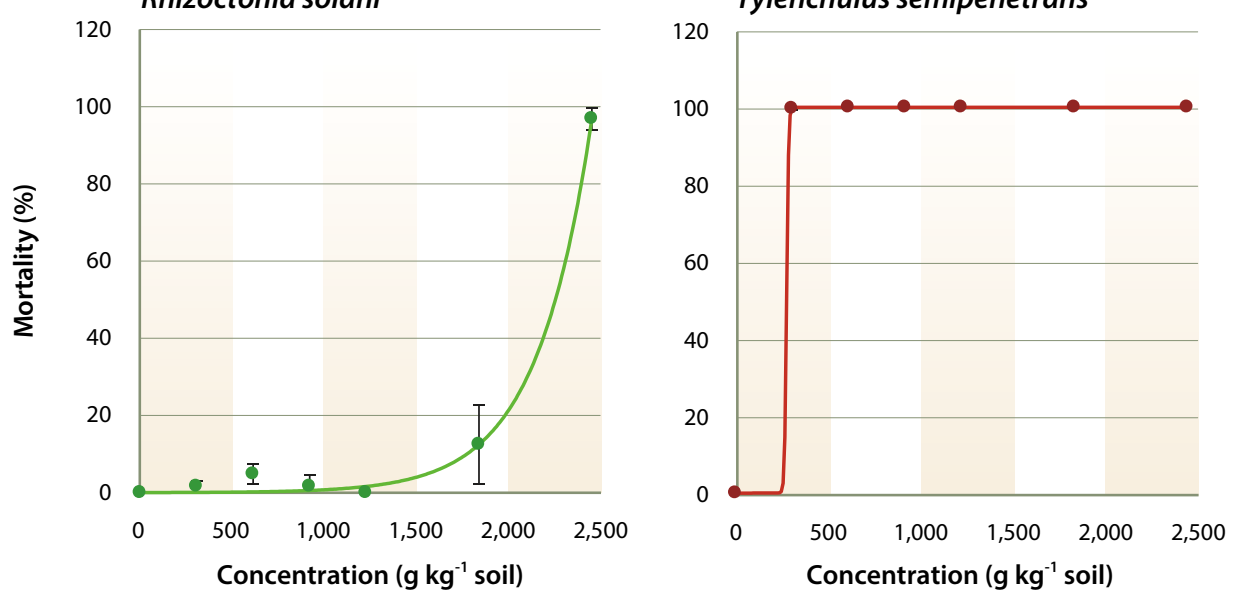

relationship between fumigant concentration and mortality (table 4).

\section{$\mathrm{MBr}: P i c$}

MBr:Pic controlled P. ultimum and T. semipenetrans and the sigmoid dose-response curves showed a significant relationship between fumigant concentration and pathogen mortality $\left(R^{2}>0.83\right)$ (fig. 1$)$. Low $\mathrm{LC}_{50}$ values were found for P. ultimum and T. semipenetrans (201.4 and $240.1 \mu \mathrm{mol}$ $\mathrm{kg}^{-1}$, respectively; table 3), and $\mathrm{MIC}_{80}$ values were 650.7 and $325.4 \mu \mathrm{mol} \mathrm{kg}{ }^{-1}$, respectively, which was less than $25 \%$ of the full concentration (table 4). A sigmoid curve and low $\mathrm{LC}_{50}$ value for $F$. oxysporum mortality $\left(395.1 \mu \mathrm{mol} \mathrm{kg}{ }^{-1}\right)$ shows the effectiveness of $\mathrm{MBr}$ :Pic with increasing concentration (fig. 1 and table 3). R. solani and $V$. dahliae were controlled only at higher concentrations (fig. 1) as reflected
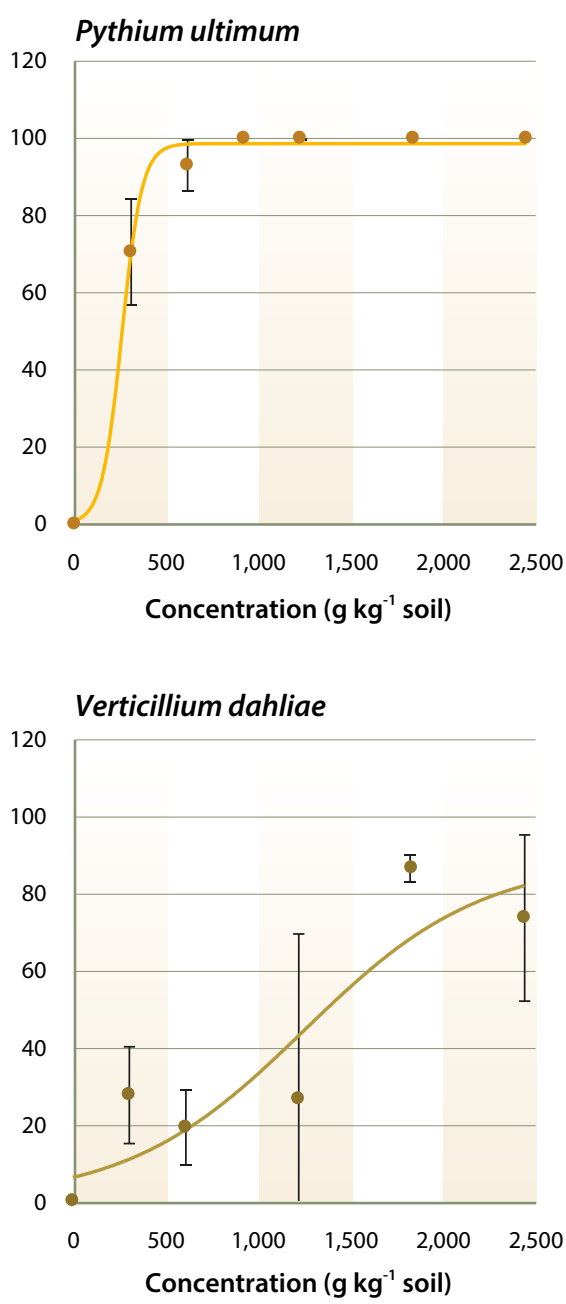

Fig. 1. Response of Fusarium oxysporum, Pythium ultimum, Rhizoctonia solani, Tylenchulus semipenetrans (citrus nematode) and Verticillium dahliae to different concentrations of Tri-Con, a mixture of $50 \%$ methyl bromide and $50 \%$ chloropicrin, in sandy loam soil after 24 hours at $20^{\circ} \mathrm{C}$. For each pathogen, $R^{2}$ values were: $0.93,0.99,0.99,1.00$ and 0.83 , respectively. Error bars represent the standard error, $n=8$. 
by high values of $\mathrm{MIC}_{80}(2,602.9$ and $2,386.0 \mu \mathrm{mol} \mathrm{kg}{ }^{-1}$, respectively; table 4 ).

\section{Ml:Pic}

All MI:Pic mixtures controlled P. ultimum and $T$. semipenetrans as reflected by low $\mathrm{LC}_{50}$ values (table 3 ) and $\mathrm{MIC}_{80}$ values using less than $25 \%$ of the full fumigant concentration (table 4). Both MI:Pic (33:67) and MI:Pic (50:50) controlled $50 \%$ of $F$. oxysporum (155.3 and $172.5 \mu \mathrm{mol} \mathrm{kg}{ }^{-1}$, respectively) and $R$. solani (215.0 and 234.1 $\mu \mathrm{mol} \mathrm{kg}{ }^{-1}$, respectively) (table 3 ). A full concentration of MI:Pic (98:2) was calculated to achieve $80 \%$ mortality of $F$. oxysporum and $R$. solani (table 4). According to $\mathrm{MIC}_{80}$ values, MI:Pic (50:50) was more effective in controlling $V$. dahliae $(862.4 \mu \mathrm{mol}$ $\mathrm{kg}^{-1}$ ) compared with MI:Pic (33:67) and MI:Pic (98:2) fumigants (2,007.0 and 914.7 $\mu \mathrm{mol} \mathrm{kg}{ }^{-1}$, respectively; table 4).

\section{Chloropicrin formulations}

The pathogens F. oxysporum, P. ultimum and T. semipenetrans were relatively sensitive to Pic 99 and Pic-Clor 60. With Pic 99,

TABLE 2. Values of the slope $b$ at the inflection point of the dose-response curve following application of tested soil fumigants for 24 hours at $20^{\circ} \mathrm{C}$

\begin{tabular}{lcccccc}
\hline & Maximum & \multicolumn{5}{c}{ Slope $(b)$} \\
\cline { 3 - 6 } Soil fumigants* & $\begin{array}{c}\text { dosaget } \\
\left(\mu \mathrm{mol} \mathrm{kg}^{-1}\right)\end{array}$ & $\begin{array}{c}\text { Fusarium } \\
\text { oxysporum }\end{array}$ & $\begin{array}{c}\text { Pythium } \\
\text { ultimum }\end{array}$ & $\begin{array}{c}\text { Rhizoctonia } \\
\text { solani }\end{array}$ & $\begin{array}{c}\text { Tylenchulus } \\
\text { semipenetrans }\end{array}$ & $\begin{array}{c}\text { Verticillium } \\
\text { dahliae }\end{array}$ \\
\hline DMDS:Pic (79:21) & $5,494.9$ & 388.4 & 11.1 & 313.9 & 17.8 & NSł \\
MBr:Pic (50:50) & $2,448.8$ & 313.6 & NS & 298.6 & NS & NS \\
MI:Pic (33:67) & $1,886.6$ & 138.1 & NS & 278.7 & NS & NS \\
MI:Pic (50:50) & $1,612.3$ & 155.9 & NS & 234.3 & NS & NS \\
MI:Pic (98:2) & 836.4 & 325.9 & NS & 219.2 & NS & NS \\
Pic 99 & $1,775.1$ & NS & NS & 149.7 & NS & NS \\
Pic-Clor 60 (57:37) & $2,004.7$ & 101.4 & NS & 85.6 & NS & NS \\
\hline
\end{tabular}

* Soil fumigants: DMDS plus Pic (79\% DMDS:21\% Pic), Tri-Con (50\% MBr:50\% Pic), Midas Gold (33\% Ml:67\% Pic), Midas Bronze (50\% Ml:50\% Pic), Midas (MI, a.i. 97.8\%), Pic (trichloronitromethane) (a.i. 99\%) and Pic-Clor 60 (57\% Pic:37\% 1,3-D).

† The maximum dose was $645 \mathrm{~kg} \mathrm{ha}^{-1}$ for DMDS:Pic (79:21), $336 \mathrm{~kg} \mathrm{ha}^{-1}$ for MBr:Pic (50:50), $336 \mathrm{~kg} \mathrm{ha}^{-1}$ for Ml:Pic (33:67), $280 \mathrm{~kg} \mathrm{ha}^{-1}$ for Ml:Pic (50:50), $140 \mathrm{~kg} \mathrm{ha}^{-1}$ for Ml:Pic (98:2), $336 \mathrm{~kg} \mathrm{ha}^{-1}$ for Pic 99 and $336 \mathrm{~kg} \mathrm{ha}^{-1}$ for Pic-Clor 60 (57:37).

$\neq$ NS $=$ Slope $(b)$ is not significant $(P>0.05)$.

TABLE 3. Values of lethal concentration (LC) calculated to control $50 \%$ of soilborne pathogens population following application of tested soil fumigants for 24 hours at $20^{\circ} \mathrm{C}$

\begin{tabular}{|c|c|c|c|c|c|}
\hline \multirow[b]{2}{*}{ Soil fumigants* } & \multirow{2}{*}{$\begin{array}{c}\text { Maximum } \\
\text { dosage } \\
\left(\mu \mathrm{mol} \mathrm{kg}{ }^{-1}\right)\end{array}$} & \multicolumn{4}{|c|}{$\begin{array}{l}\mathrm{LC}_{50}, \mu \mathrm{mol} \mathrm{kg}^{-1} \\
\text { (Lower limit, upper limit) }\end{array}$} \\
\hline & & $\begin{array}{l}\text { Fusarium } \\
\text { oxysporum }\end{array}$ & $\begin{array}{l}\text { Pythium } \\
\text { ultimum }\end{array}$ & $\begin{array}{l}\text { Rhizoctonia } \\
\text { solani }\end{array}$ & $\begin{array}{c}\text { Tylenchulus } \\
\text { semipenetrans }\end{array}$ \\
\hline DMDS:Pic (79:21) & $5,494.9$ & $\begin{array}{c}1,095.5 \\
(642.9,1,458.6)\end{array}$ & $\begin{array}{c}507.0 \\
(127.0,848.4)\end{array}$ & $\begin{array}{c}1,068.3 \\
(748.8,1,387.1)\end{array}$ & $\begin{array}{c}588.5 \\
(269.1,874.4)\end{array}$ \\
\hline MBr:Pic (50:50) & $2,448.8$ & $\begin{array}{c}395.1 \\
(208.3,557.5)\end{array}$ & $\begin{array}{c}201.4 \\
(14.3,390.8)\end{array}$ & $\begin{array}{c}193.7 \\
(\mathrm{NA} \neq, \mathrm{NA})\end{array}$ & $\begin{array}{c}240.1 \\
(\mathrm{NA}, \mathrm{NA})\end{array}$ \\
\hline MI:Pic (33:67) & $1,886.6$ & $\begin{array}{c}155.3 \\
(22.5,327.6)\end{array}$ & $\begin{array}{c}185.2 \\
(\mathrm{NA}, \mathrm{NA})\end{array}$ & $\begin{array}{c}215.0 \\
(108.3,334.1)\end{array}$ & $\begin{array}{c}\mathrm{NA} \\
(\mathrm{NA}, \mathrm{NA})\end{array}$ \\
\hline MI:Pic (50:50) & $1,612.3$ & $\begin{array}{c}172.5 \\
(60.6,281.2)\end{array}$ & $\begin{array}{c}191.0 \\
(110.3,257.3)\end{array}$ & $\begin{array}{c}234.1 \\
(112.2,348.2)\end{array}$ & $\begin{array}{c}172.5 \\
(\mathrm{NA}, \mathrm{NA})\end{array}$ \\
\hline MI:Pic (98:2) & 836.4 & $\begin{array}{c}91.5 \\
(2.5,416.4)\end{array}$ & $\begin{array}{c}104.5 \\
(66.1,143.1)\end{array}$ & $\begin{array}{c}39.2 \\
(\mathrm{NA}, \mathrm{NA})\end{array}$ & $\begin{array}{c}\mathrm{NA} \\
(\mathrm{NA}, \mathrm{NA})\end{array}$ \\
\hline Pic 99 & $1,775.1$ & $\begin{array}{c}145.6 \\
(13.9,284.0)\end{array}$ & $\begin{array}{c}196.0 \\
(93.7,271.4)\end{array}$ & $\begin{array}{c}235.2 \\
(151.1,331.0)\end{array}$ & $\begin{array}{c}196.0 \\
(101.5,293.6)\end{array}$ \\
\hline Pic-Clor 60 (57:37) & $2,004.7$ & $\begin{array}{c}311.0 \\
(158.0,433.5)\end{array}$ & $\begin{array}{c}241.2 \\
(136.3,318.2)\end{array}$ & $\begin{array}{c}215.8 \\
(115.8,322.9)\end{array}$ & $\begin{array}{c}12.1 \\
(\mathrm{NA}, \mathrm{NA})\end{array}$ \\
\hline
\end{tabular}

The values of $L C_{50}$ were calculated from the dose-response curve for each pathogen and each fumigant. Confidence interval estimates are in parentheses $(P<0.05), n=8$.

* Soil fumigants: DMDS plus Pic (79\% DMDS:21\% Pic), Tri-Con (50\% MBr:50\% Pic), Midas Gold (33\% Ml:67\% Pic), Midas Bronze (50\% Ml:50\% Pic), Midas (MI, a.i. 97.8\%), Pic (trichloronitromethane) (a.i. 99\%) and Pic-Clor 60 (57\% Pic:37\% 1,3-D).

†The maximum dose was $645 \mathrm{~kg} \mathrm{ha}^{-1}$ for DMDS:Pic (79:21), $336 \mathrm{~kg} \mathrm{ha}^{-1}$ for MBr:Pic (50:50), $336 \mathrm{~kg} \mathrm{ha}^{-1}$ for Ml:Pic (33:67), $280 \mathrm{~kg} \mathrm{ha}^{-1}$ for Ml:Pic (50:50), $140 \mathrm{~kg} \mathrm{ha}^{-1}$ for Ml:Pic (98:2), $336 \mathrm{~kg} \mathrm{ha}^{-1}$ for Pic 99 and $336 \mathrm{~kg} \mathrm{ha}^{-1}$ for Pic-Clor 60 (57:37).

$\neq \mathrm{NA}=$ Not applicable. $\mathrm{LC}_{50}$ values for $\mathrm{V}$. dahliae could not be calculated from a probit model.
$\mathrm{LC}_{50}$ values for F. oxysporum, P. ultimum and T. semipenetrans were 145.6, 196.0 and $196.0 \mu \mathrm{mol} \mathrm{kg}{ }^{-1}$, respectively; with Pic-Clor 60, LC $_{50}$ values were 311.0, 241.2 and $12.1 \mu \mathrm{mol} \mathrm{kg}{ }^{-1}$, respectively (table 3). Low values of $\mathrm{LC}_{50}$ were also calculated for $R$. solani following Pic 99 and Pic-Clor 60 application (235.2 and $215.8 \mu \mathrm{mol} \mathrm{kg}{ }^{-1}$, respectively; table 3 ), and half the full rate controlled $80 \%$ of $R$. solani (940.8 and $1,066.2 \mu \mathrm{mol} \mathrm{kg}{ }^{-1}$, respectively; table 4). Neither Pic 99 nor Pic-Clor 60 (57:37) was effective in controlling $V$. dahliae, and $\mathrm{MIC}_{80}$ values were 1,414.6 and 1,349.3 $\mu \mathrm{mol} \mathrm{kg}{ }^{-1}$, respectively (table 4 ).

\section{Discussion}

Although some information is available on the efficacy of chloropicrin against soilborne pathogens, little is known about the efficacy of commercial formulations of DMDS:Pic and Midas. Results from this study indicate that, in several cases, effective control of some pathogens was achieved with these mixtures at dosages below the maximum label rate.

The fumigants DMDS:Pic and Pic-Clor 60 controlled almost all tested pathogens. The largest slope at the inflection point of the curve ( $b$ value) indicated that $F$. oxysporum and $R$. solani have greater susceptibility to pure MI (MI:Pic, 98:2) than to the other fumigants (table 2). Early doseresponse studies evaluated the efficacy of pure $\mathrm{MI}$ and $\mathrm{MBr}$ to control a range of soilborne pathogens and found P. ultimum to be the most sensitive and $R$. solani to be the least sensitive (Hutchinson et al. 2000; Ohr et al. 1996), and only partial mortality of F. oxysporum and V. dahliae was achieved with these fumigants. Other studies have reported that $\mathrm{MI}$ and $\mathrm{MBr}$ controlled nematodes, including citrus nematode (Becker et al. 1998; Hutchinson et al. 1999; Luo et al. 2010). Also, a doseresponse study on the efficacy of InLine (Klose et al. 2007) found that P. ultimum was the most sensitive and $V$. dahliae the least sensitive, and a partial mortality was achieved for F. oxysporum. In general, our results (table 4) indicate that P. ultimum was the most sensitive and $V$. dahliae was most resistant.

DMDS:Pic controlled P. ultimum and T. semipenetrans at low dosages. Ten percent of the full concentration (label rate of $5,494.9 \mu \mathrm{mol} \mathrm{kg}{ }^{-1}$ is equivalent to 645 $\mathrm{kg} \mathrm{ha}^{-1}$ or $576 \mathrm{lb} \mathrm{ac}^{-1}$ ) was calculated to 
control $50 \%$ of P. ultimum and T. semipenetrans. Good control of F. oxysporum and $R$. solani was achieved using $20 \%$ of the full DMDS:Pic concentration. In previous laboratory studies, DMDS:Pic was found to be effective against citrus nematode (Cabrera et al. 2010) and $R$. solani (Fritsch et al. 2002) and partially effective against $F$. oxysporum $\mathrm{f}$. sp. radicislycopersici (Abraham Gamliel, professor, ARO Volcani Center, Israel, unpublished data). Also in prior studies under field conditions, effective control was achieved for $R$. solani and $V$. dahliae at a rate of 600 $\mathrm{kg} \mathrm{ha}^{-1}$ with VIF in France (Fritsch 2004). However, in our study, only $60 \%$ mortality of $V$. dahliae was detected following full concentration application $\left(645 \mathrm{~kg} \mathrm{ha}^{-1}\right.$, which is equal to $\left.5,494.9 \mu \mathrm{mol} \mathrm{kg}{ }^{-1}\right)$. Our results suggest that DMDS can provide satisfactory control of selected soilborne pathogens, but more field experiments are required.

The mixture of MBr:Pic (50:50) was used instead of the traditional MBr:Pic (67:33) mixture because of commercial formulation changes with the phaseout of $\mathrm{MBr}$. In addition, the MBr:Pic (50:50) mixture served as a good benchmark against the MI:Pic (50:50) formulation. The MBr:Pic (50:50) mixture controlled P. ultimum and T. semipenetrans but was not effective on $R$. solani and $V$. dahliae. Only one-tenth of the full concentration was needed for $50 \%$ control of P. ultimum and T. semipenetrans $\left(\mathrm{LC}_{50}\right)$, and $80 \%$ mortality was achieved using less than 25\% of the full concentration (tables 3 and 4). F. oxysporum mortality increased with increasing concentration of MBr:Pic (fig. 1 and table 3 ). $R$. solani and $V$. dahliae were controlled only by higher concentrations at 2,602.9 and 2,386.0 $\mu \mathrm{mol} \mathrm{kg}{ }^{-1}$, respectively (table 4).

Most MBr efficacy studies have assessed the dose response using pure $\mathrm{MBr}$ $(98 \%)$ and found this compound very effective against a wide range of pests; however, the analog compound, MI, was found to be as effective as or more effective than $\mathrm{MBr}$ (Becker et al. 1998; Hutchinson et al. 1999; Hutchinson et al. 2000; Ohr et al. 1996; Zhang et al. 1997). In this study, the mixed fumigants MBr:Pic

Tarping fields helps to retain fumigants in soil.

TABLE 4. Values of the minimum $80 \%$ inhibitory concentration $\left(\mathrm{MIC}_{80}\right.$ ) calculated to control $80 \%$ of soilborne pathogens following application of tested soil fumigants for 24 hours at $20^{\circ} \mathrm{C}$

\begin{tabular}{|c|c|c|c|c|c|c|}
\hline \multirow[b]{2}{*}{ Soil fumigants* } & \multirow{2}{*}{$\begin{array}{c}\text { Maximum } \\
\text { dosaget } \\
\left(\mu \mathrm{mol} \mathrm{kg}{ }^{-1}\right)\end{array}$} & \multicolumn{5}{|c|}{$\mathrm{MIC}_{80}\left(\mu \mathrm{mol} \mathrm{kg}{ }^{-1}\right)$} \\
\hline & & $\begin{array}{l}\text { Fusarium } \\
\text { oxysporum }\end{array}$ & $\begin{array}{l}\text { Pythium } \\
\text { ultimum }\end{array}$ & $\begin{array}{l}\text { Rhizoctonia } \\
\text { solani }\end{array}$ & $\begin{array}{l}\text { Tylenchulus } \\
\text { semipenetrans }\end{array}$ & $\begin{array}{c}\text { Verticillium } \\
\text { dahliae }\end{array}$ \\
\hline DMDS:Pic (79:21) & $5,494.9$ & $2,920.6$ & $1,460.3$ & $4,380.0$ & 730.6 & $3,750.8$ \\
\hline MBr:Pic (50:50) & $2,448.8$ & $1,301.4$ & 650.7 & $2,602.9$ & 325.4 & $2,386.0$ \\
\hline MI:Pic (33:67) & $1,886.6$ & 752.6 & 250.9 & $1,505.3$ & 250.9 & $2,007.0$ \\
\hline Ml:Pic (50:50) & $1,612.3$ & 862.4 & 216.2 & $1,293.6$ & 216.2 & 862.4 \\
\hline MI:Pic (98:2) & 836.4 & 914.7 & 229.3 & $1,452.4$ & 116.3 & 914.7 \\
\hline Pic 99 & $1,775.1$ & 470.4 & 235.2 & 940.8 & 235.2 & $1,414.6$ \\
\hline Pic-Clor 60 (57:37) & $2,004.7$ & 533.1 & 266.6 & $1,066.2$ & 266.6 & $1,349.3$ \\
\hline
\end{tabular}

* Soil fumigants: DMDS plus Pic (79\% DMDS:21\% Pic), Tri-Con (50\% MBr:50\% Pic), Midas Gold (33\% Ml:67\% Pic), Midas Bronze (50\% Ml:50\% Pic), Midas (MI, a.i. 97.8\%), Pic (trichloronitromethane) (a.i. 99\%) and Pic-Clor 60 (57\% Pic:37\% 1,3-D).

† The maximum dose was $645 \mathrm{~kg} \mathrm{ha}^{-1}$ for DMDS:Pic (79:21), $336 \mathrm{~kg} \mathrm{ha}^{-1}$ for MBr:Pic (50:50), $336 \mathrm{~kg} \mathrm{ha}^{-1}$ for Ml:Pic (33:67), $280 \mathrm{~kg} \mathrm{ha}^{-1}$ for Ml:Pic (50:50), $140 \mathrm{~kg} \mathrm{ha}^{-1}$ for Ml:Pic (98:2), $336 \mathrm{~kg} \mathrm{ha}^{-1}$ for Pic 99 and $336 \mathrm{~kg} \mathrm{ha}^{-1}$ for Pic-Clor 60 (57:37).

(50:50) and MI:Pic (50:50) both controlled T. semipenetrans, P. ultimum and F. oxysporum, but MI:Pic was more effective in controlling $R$. solani compared to MBr:Pic (tables 3 and 4).

The data for MI:Pic mixture efficacy is mainly assessed under field conditions and is measured by yield (Browne et al. 2006; Gilreath et al. 2003; Schneider et al. 2008). However, our study assessed the efficacy of the mixtures MI:Pic (33:67), MI:Pic (50:50) and MI:Pic (98:2) under controlled conditions. All three formulations controlled P. ultimum and T. semipenetrans. Only $12.5 \%$ of the full concentration was required to control half of $P$. ultimum and T. semipenetrans ( $\mathrm{LC}_{50}$ values, table 3 ), and $80 \%$ mortality (table 4 ) was achieved by using less than $25 \%$ of the full concentration of each fumigant. Based on the $\mathrm{MIC}_{80}$ values, reduced concentrations of MI:Pic (33:67) and MI:Pic (50:50) controlled tested pathogens better than MI:Pic (98:2) (table 4), which may indicate that adding chloropicrin to MI improved the efficacy of MI:Pic mixtures. This result is consistent with research that found combining two fumigants may result in synergy or competitive relationships between the compounds in the mixture (Gamliel and Triky-Dotan 2009; Hutchinson et al. 2000; Zheng et al. 2003).

Another reason to include Pic-Clor 60 in this study was to compare its efficacy with that of Pic 99. The additional 1,3-D in the Pic-Clor 60 mixture did not improve efficacy compared with Pic 99. Both fumigants had similar $\mathrm{MIC}_{80}$ values, indicating effective mortality of F. oxysporum, P. ultimum, R. solani and T. semipenetrans (table 4). Neither chloropicrin formulation controlled $V$. dahliae, and the $\mathrm{MIC}_{80}$ values for Pic 99 and Pic-Clor 60 (1,414.6 and 1,349.3 $\mu \mathrm{mol} \mathrm{kg}{ }^{-1}$, respectively) were calculated assuming a linear relationship of increasing concentration and mortality (table 4 ).

Incomplete mortality of $V$. dahliae $(60 \%$ to $80 \%$ ) was observed with all tested

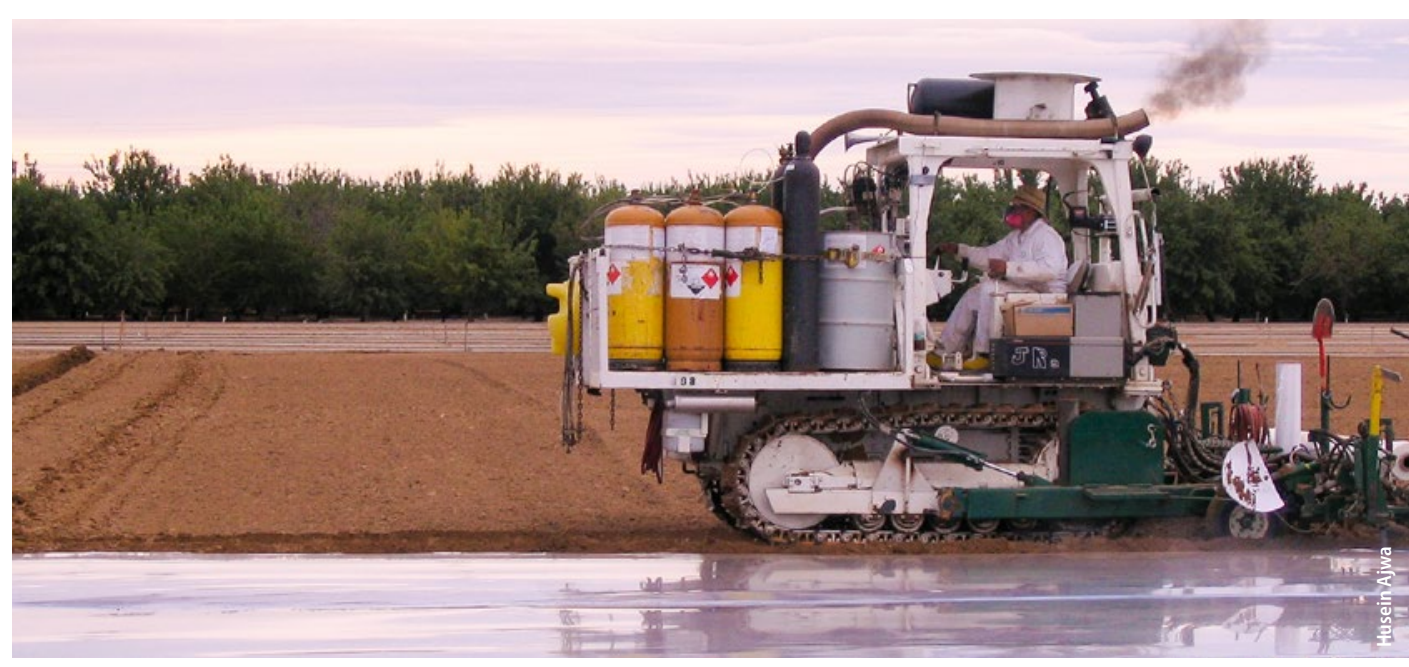


fumigants at full concentration except for MI:Pic (50:50), which achieved $80 \%$ mortality with half the full concentration (table 4). The multivariate analysis (ANOVA) for the effects of fumigants and the interactions between fumigants and rates on $V$. dahliae mortality were not significant $(P<0.05)$ (table 1$)$. The resistance of $V$. dahliae may occur because its resting form in soil (microsclerotia) is difficult for fumigants to penetrate (Klose et al. 2007). Note that this study evaluated a fumigant dose-response over a 24-hour period. Earlier studies (Klose et al., 2007 and 2008) found that fumigants in a closed system reach equilibrium within minutes after application, and a 24-hour incubation period is sufficient to assess pathogen mortality following soil fumigant application. However, increasing exposure time of the pathogen to fumigants in combination with other disinfestation methods and other fumigants may increase efficacy against this pathogen. For example, using TIF or VIF, the effective dose can be higher due to longer exposure times (Fennimore and Ajwa 2011).

The results indicate that the maximum application rate for commonly used fumigants may be insufficient to control important pathogens. For example, the maximum allowable application rate of MBr:Pic (50:50), the most commonly used fumigant, is insufficient to inhibit more than $80 \%$ of $V$. dahliae (table 4 ). For this same pathogen, however, this study also suggests that an application rate of 226 $\mathrm{kg} \mathrm{ha}^{-1}$ of Pic-Clor $60\left(1,349.3 \mu \mathrm{mol} \mathrm{kg}{ }^{-1}\right.$ relative to the maximum label rate 2,004.7 $\mu \mathrm{mol} \mathrm{kg}{ }^{-1}$ ) can control $80 \%$ of $V$. dahliae (table 4).

Although our results show that for certain pathogens, such as P. ultimum, the recommended maximum label rate was often higher than the minimum effective dose, the actual effective dose under field conditions may vary widely, depending on soil type, soil preparation, soil temperature, soil moisture, type of pathogen complex in the soil, pathogen distribution in soil and the type of tarp used to seal in the fumigants. Maximum label rate is usually recommended to ensure the control of the diverse weed and pathogen populations in soils. However, prefumigation soil testing for pathogens and historic farm weed and pest pressure will aid growers in determining minimum application rates.
Results presented in this study can be used to compare the reactivity of the commercial formulations to each other for specific pathogens and show that application rates can be based on the type of pathogen and degree of infestation. However, extrapolating the results to field conditions should be done with caution. This study provides basic information to reduce pathogen populations to levels where natural biological feedback mechanisms can function to regulate disease outbreaks. However, further research is needed on fumigant efficacy as a function of soil type under field conditions for various crops and their cultivars. $C A$

\section{S. Triky-Dotan is Postdoctoral Research Associate and B. Westerdahl is Professor and UC Cooperative Extension (UCCE) Specialist in the Department of Plant Sciences at UC Davis; F.N. Martin is Research Scientist at ARS- USDA, Salinas; K. Subbarao is UCCE Specialist in the Department of Plant Pathology at UC Davis; S.T. Koike is UCCE Farm Advisor in Monterey County; H.A. Ajwa is UCCE Specialist in the Department of Plant Sciences at UC Davis.}

\section{References}

Ajwa HA, Klose S, Nelson S, et al. 2003. Alternatives to methyl bromide in strawberry production in the United States of America and the Mediterranean region. Phytopathol Mediterr 42:220-44.

Becker JO, Ohr HD, Grech NM, et al. 1998. Evaluation of methyl iodide as a soil fumigant in container and small field plot studies. Pestic Sci 52:58-62.

Browne GT, Connell JH, Schneider SM. 2006. Almond replant disease and its management with alternative pre plant soil fumigation treatments and rootstocks. Plant Dis 90:869-76.

Cabrera JA, Gan J, Hanson BD, Wang D. 2010. Factors affecting the nematicidal activity of dimethyl disulfide. Annual International Research Conference on Methyl Bromide Alternatives. Orlando, FL. p. 5-1-5-2.

California Strawberry Comission. 2016. About strawberries. www.californiastrawberries.com/about_strawberries. [CDPR] California Department of Pesticide Regulation. 2009. Volatile organic compound (VOC) emissions from pesticides. www.cdpr.ca.gov/docs/emon/vocs/vocproj/ vocmenu.htm.

Fennimore S, Ajwa H. 2011. Totally impermeable film retains fumigants, allowing lower application rates in strawberry. Calif Agr 65:211-15.

Fritsch J. 2004. Dimethyl disulfide as a new chemical potential alternative to methyl bromide in soil disinfestation in France. VI International Symposium on Chemical and non-Chemical Soil and Substrate Disinfestations. ISHS Acta Hort 698:71-3.
Fritsch J, Baudry A, Aubert T. 2002. Dimethyl disulfide as a new potential alternative to methyl bromide for soil disinfestation. In: Proceedings of the International Conference on Alternatives to Methyl Bromide, Mar. 5-8, 2002. Seville, Spain. p. 340

Gamliel A, Triky-Dotan S. 2009. Accelerated degradation of soil fumigants: occurrence and agricultural consequences. In: Gisi U, Chet I, Gullino ML (eds.). Recent Developments in Management of Plant Diseases. Plant Pathology in the $21^{\text {st }}$ Century (Vol. 1). Netherlands: Springer. p 311-28.

Gao S, Ajwa H, Qin R, et al. 2013. Emission and transport of 1,3-dichloropropene and chloropicrin in a large field tarped with VaporSafe TIF. Environ Sci Technol 47:405-11. Gilreath J, Jones J, Motis T, et al. 2003. Evaluation of various chemical treatments for potential as methyl bromide replacements for disinfestations of soiborne pests in polyethylene-mulched tomato. Proc FI State Hort Soc 116:151-58.

Hutchinson CM, McGiffen ME, Ohr HD, et al. 1999. Efficacy of methyl iodide soil fumigation for control of Meloidogyne incognita, Tylenchulus semipenetrans, and Heterodera schachtii. Nematology 1:407-14.

Hutchinson CM, McGiffen ME, Ohr HD, et al. 2000. Efficacy of methyl iodide and synergy with chloropicrin for control of fungi. Pest Manag Sci 56:413-18.

Klose S, Ajwa HA, Fennimore SA, et al. 2007. Dose response of weed seeds and soilborne pathogens to 1,3-D and chloropicrin. Crop Prot 26:535-42.
Klose S, Ajwa HA, Browne GT, et al. 2008. Dose response of weed seeds, plant-parasitic nematodes, and pathogens to twelve rates of metam sodium in a California soil. Plant Dis 92:1537-46.

Luo LF, Yates S, Ashworth D, Dungan R. 2010. Transport and fate of Mel and its pest control in soils. Environ Sci Technol 44:6275-80.

Martin FN. 2003. Development of alternative strategies for management of soilborne pathogens currently controlled with methyl bromide. Annu Rev Phytopathol 41:325-50.

Ohr HD, Sims J, Grech NM, et al. 1996. Methyl iodide, an ozone-safe alternative to methyl bromide as a soil fumigant. Plant Dis 80:731-35

Qin R, Gao S, Ajwa H, et al. 2011. Field evaluation of a new plastic film (Vapor Safe) to reduce fumigant emissions and improve distribution in soil. J Environ Qual 40:1195-1203

Schneider SM, Ajwa HA, Trout TJ, Gao S. 2008. Nematode control from shank- and drip-applied fumigant alternatives to methyl bromide. HortScience 43:1826-32.

[USEPA] U.S. Environmental Protection Agency. 2015. Implementing safety measures. Risk mitigation (safety) measures for soil fumigants. www.epa.gov/soil-fumigants/implementing-safety-measures.

Zhang WM, McGiffen ME Jr, Becker JO, et al. 1997. Dose response of weeds to methyl iodide and methyl bromide. Weed Res 37:181-89.

Zheng W, Papiernik SK, Guo M, Yates SR. 2003. Competitive degradation between the fumigants chloropicrin and 1,3-dichloropropene in unamended and amended soils. J Environ Qual: 32:1735-42. 